Dept. of Zoology,

Fac. of Science,

Head of Dept. Prof. Dr. E.G. Yoakim

\title{
EFFECT OF COMBINED ADMINISTRATION OF ESTROGEN \\ AND PROGESTERONE ON THE HISTOLOGICAL AND \\ HISTOCHEMICAL FEATURES OF LIVER AND SPLEEN IN FEMALE NON-LACTATING RATS \\ (With 5 Plates)
}

By

M.A. ATTIA; A.T.G. AHMED*; SOAD S. ALI** and SADIA R.***

(Received at 18/4/1994)

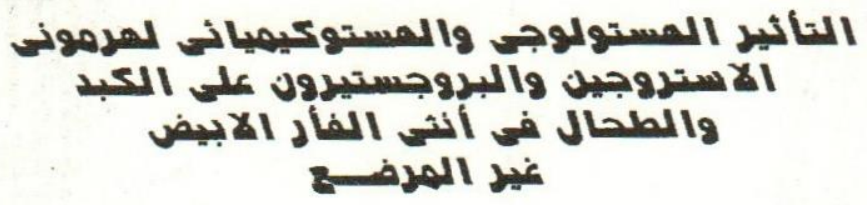

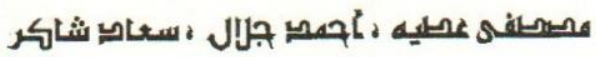

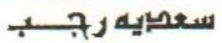

تم حقن اناث الفأر الأبيض غير المرفع بجروعات محات محدده من خليط من هرمونى الاستروجين

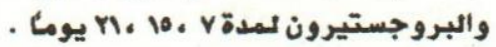

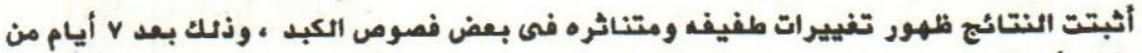

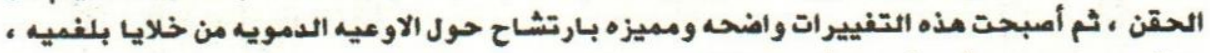

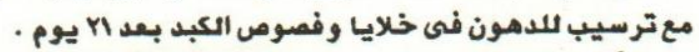

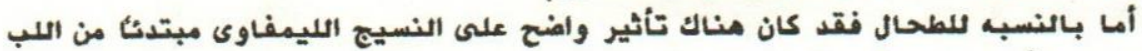

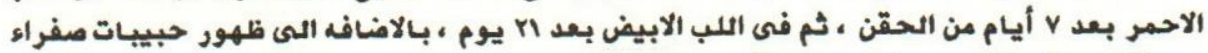

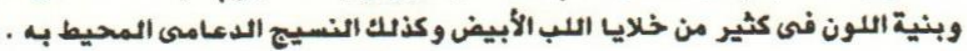

*: Dept. of Anatomy Assiut university

**: Dept. of Histology Assiut University

**: Dept. of Histology El-Minia University

Assiut Vet. Med. J. Vol. 31. No 62, July 1994. 


\section{SUMMARY}

Estrogen (E) and progesterone (P) are usually used in combination for preparation of many contraceptive formulations. As these hormones are mainly metabolized in liver and due to their intimate relationship to the immune system, the present work was done to declair their effect on Yiver and spleen in non-lactating rats. The results show that injection of a combination of both hormones in a dose of 90 (E) and 450 (P) ug/200 gm body weight in nonlactating female albino rats results in several morphological changes both in liver and spleen. After 7 days of injection the liver developed focal changes in some lobules, dilatation of blood sinusoids and slight fibrosis of portal areas. At 21 days a marked cellular infiltration around the blood sinusoids and in the portal areas were observed. Depletion of glycogen and increase in DNA content was noticed in hepatocytes. On the other hand; the spleen showed marked changes of lymphoid elements both in the red and the white pulp.

Keywords: Estrogen, progestrone, histological, histochemical, liver, spleen, female non-lactating rats.

\section{INTRODUCTION}

Female sex hormones; estrogen and progesterone are commonly used in combination in most contraceptive preparations (GOODMAN et al. 1991). Their undesirable effects on the target organs; namely ovaries; genital tract and mammary glands had been widely investigated (BOSEILA et al., 1985).

As these hormones are metabolized in the liver, their drastic effects on the histology and histochemistry of liver were subjected to many studies (ADIEB, et al., 1986). The effect of either estrogen or progesterone on immune system is questionable. Few researches dealt with their effect on the thymus gland (GHOLI et al., 1984). However, very little was mentioned about the effect of the two hormones on the structure of spleen (SASAKI and ITO; 1981).

For these reasons, the present work aims to study the effect of a combination of estrogen and progesterone on the histological and histochemical appearance of the liver and spleen in female non-lactating rats.

Assiut Vet. Med. J. Vol. 31 No. 62, July 1994. 


\section{MATERIAL AND METHODS}

\section{Animal used \& drug administration:}

Twenty non-lactating female rats aging about 4-6 months and weighing about 200-250 $\mathrm{g}$ were used. The animals were divided into four groups, each was consisted of five animals. The first group served as control, the other three groups received daily intramuscular injections of estrogen and progesterone dissolved in seaseme oil in a dose of $90 \mathrm{ug}$ and 450 ug respectively. The control group was injected with seaseme oil only. The dose of the hormone was calculated according to the surface area in relation to man (GHOSH, 1971).

Histological and Histochemical Technique:

All rats were killed after 7,15 and 21 days from the first injection. Specimens from the liver and spleen of all animals were fixed in formol-alcohol. Paraffin sections 7-10 um thick were prepared and stained with haematoxylin and eosin, for histological studies. PAS reaction was applied to the sections for the demonstration of polysaccharides and Feulgen reaction for DNA of spleen (DRURY \& WALLINGTON, 1980).

\section{RESULTS}

\section{Histological and Histochemical Findings in the Liver:}

The liver of the control non-lactating female rat is formed of ill-defined lobules which are demarcated by the presence of portal areas at their periphery (Plate I Fig. 1). Hepatocytes are arranged in anastomosing plates radiating from the central vein and separated by blood sinusoids. The cytoplasm of hepatocytes is slightly acidophilic with varying amounts basophilic granules.

Seven days after combined estrogen and progesterone administration, the liver showed focal histological changes. Some areas exhibited an increase in the granular appearance of liver cells, an increased acidophilia together with sinusoidal dilation and mild cellular infiltration mainly of the lymphocyte variety. Some specimens showed dilatation of both central and portal veins (Plate I Fig. 2 a \& b). The nuclei of hepatocytes became more vesicular and the amount of binucleated cells increased compared to the control.

After 15 days of hormonal treatment, there was a slight disturbance in liver architecture. Many liver cells appeared binucleated and frequent mitotic figures are present. Sinusoidal dilation and cellular infiltration became more evident (Plate I, Fig. 3a \& b).

Assiut Vet. Med. J. Vol. 31 No. 62, July 1994. 
21 days after administration, hypertrophy of liver cells with degeneration of their nuclei and vacuolation of their cytoplasm were observed (Plate I, Fig. 4 a \& b).

PAS technique revealed that the hepatocytes of the control rat contained abundant amount of polysaccharides which appeared in the form of accumulated deep purple granules shifted to one side of the cells. The amount of these polysaccharide contents varied among the liver cells (Plate II, Fig. 1). After 7 days of combined hormonal administration there was a great increase in polysaccharide content of hepatocytes (Plate II, Fig. 2).

Fifteen days after hormonal administration, polysaccharide, depletion in the affected areas was observed-especially in the peripheral parts of the lobules (Plate II, Fig. 3). Continuous depletion of polysaccharides occured with further administration of estrogen and progesterone for 21 days (Plate II, Fig. 4).

\section{Histological and Histochemical Findings in the Spleen:}

The spleen of control non-lactating female rat is enclosed into a fibrous capsule which sends few thin trabeculae dividing the organ into communicating compartments. Both the capsule and trabeculae show PAS- positive reaction (Plate IV, Fig. 1). While the cytoplasm and the nuclei of lymphocytes show negative PAS reaction. The parenchyma of control spleen is formed of red pulp and white pulp. The red pulp is characteristically large and composed of numerous thin walled blood sinusoids that ramify among the splenic cords which is formed of various mature and immature blood elements (Plate III, Fig. 1). The white pulp is formed of a cylindrical mass of lymphocytes, the lymphoid follicles. Each follicle shows lymphocytes with deeply stained nuclei surrounding the pale central part, the germinal center (Plate III, Fig. 1).

Feulgen reaction revealed that the nuclei of the cells in the periarterial sheath showed an intense reaction (Plate $V$, Fig. 1).

After 7 days of the combined estrogen and progesterone treatment, there is a slight thickening of the splenic capsule and septa which are stained intensely with PAS (Plate IV, Fig. 2 ). The white pulp of the spleen was larger when compared with control (Plate III, Fig. 2). The germinal centers exhibited numerous mitotic figures. There was a slight increase in the cell density of the red pulp with a slight sinusoidal dilation. Slight increase in the Feulgen reaction was observed compared to control (Plate V Fig. 2).

Further hormonal treatment for 15 and 21 days led to depletion of lymphocytes in both red and white pulp, the nuclei

Ass1ut Vet. Med. J. Vol. 31 No. 62, July 1994. 
of the cells showed intense reaction for PAS (Plate IV, Fig. $3)$. The use of Feulgen's reaction indicated that the nuclei of lymphocytes showed deeply stained clumps of DNA (Plate V, Fig. 3).

Some specimens, at 21 days of hormonal treatment showed sinusoidal dilatation and congestion (Plate III, Fig. 3). These specimens showed accumulation of yellowish or brownish granules both extra-and intracellular in either white or red pulp.

\section{DISCUSSION}

The present study revealed that the administration of a mixture of estrogen and progesterone to female non-lactating albino rats led to histological and histochemical changes in the liver and spleen depending on the period of administration.

Changes in the Liver:

It was noticed that after seven days of hormonal treatment, the cytoplasm of hepatocytes became more acidophilic and granular. The same observation was given by GERSHBERG et al. (1969) and $A D I E B$ et al. (1986) in liver cells of rat after female sex hormone administration. This could be attributed to the fact that sex hormones remain in hepatocyte to be metabolized with subsequent increase in the smooth endoplasmic reticulum and swollen mitochondria resulting in an increase in cellular granularity. NASONOV (1959) forwarded the same explanations.

The dilatation of the central veins and hepatic sinusoids could be related to hepatic congestion that may have developed during the course of hormonal treatment (BOSEILA; et al., 1985). Similar results were obtained after both estrogen (FUGII et $\underline{\text { al. }}, 1985$ ) and Medroxy-progesterone acetate (ADIEB et al. , 1986), where the two authors observed central vein and blood sinusoid dilatation in the liver of rats after hormonal treatment. EDRIS et al. (1972) and ADIEB et al. (1986) attributed this dilatation to the possibility of occurence of portal hypertension which was reported to coincide with the injection of contraceptive drugs and manifested clinically by the presence of piles and varicose veins. According to the present work, the blood sinusoids and portal area showed cellular infiltration which may be most probably migratory cells from the blood circulation. This may be attributed to the noticeable congestion of the hepatic vessels particularly the sinusoids.

Assiut Vet. Med. J. Vol. 31 No. 62, July 1994. 
An inflammatory reaction at the surrounding liver cells had not any degenerative signs. The same interpretation was given by BESHIR et al. (1987).

With prolonged hormonal treatment (after 21 days), the present results cleared that the liver cells showed vacuolation and degeneration of their nuclei. These changes were interpreted by many authors to be due to fatty changes resulting from prolonged hormonal treatment (CHAMNESS et al. , 1975; BEERS \& ROSNER, 1977 and BOSEILA, et al., 1985). Another point of view based on the fact that female sex hormones lead to stimulation of adrenal cortex, the subsequent release of cortisone may cause this vacuolation as reported by BIRCHMEIER (1969).

Histochemical observations revealed that there was an initial increase in PAS positive material of hepatocytes started at seven days after hormonal treatment. With continuous treatment focal depletion was noticed in liver lobules. The initial increase may be due to an increase in hepato-cellular activities to metabolize the two hormones (SANG and KAPPAS, 1969). Reports of pronounced increase in glycogen content in experimental animals treated with estrogen were generally described by WALLAAS (1952) and INGLE (1959). On the same time GAUNT et al. (1939) and BECK (1969) reported that short term administration of low doses of progesterone raises hepatic glycogen content by increasing both growth hormones and insuline level in blood. Also, increase glycogen content could be caused by stimulation of cortisone secretion from adrenal glands (BIRCHMEIER, 1969).

The glycogen depletion of hepatocytes after 15 and 21 days of hormonal treatment may be explained by direct toxic effects of hormonal metabolities (EL-NAGGAR et al., 1986).

\section{Changes in the spleen:}

According to the present investigation; the combination of the estrogen and progesterone produced structural changes in spleen. These changes were time dependent; the two hormones produced initial stimulation of lymphoid elements; the white pulp became large with wide active germinal center whereas the red pulp showed slight changes. With continuous treatment for 15 and 21 days lymphocytic depletion in white pulp, beside dilatation and congestion of blood sinusoids in the red pulp occured. The present results are in agreement with the observations of SASAKI \& ITO (1981) who reported that the splenic white pulp was relatively resistant to female sex hormones.

Assiut Vet. Med. J. Vol. 31 No. 62, July 1994. 
The present work showed that the white pulps were more influenced than red pulps. This contradict the results of ANAGNOSTOU et al., (1976) and SASAKI and ITO (1981). HOWEVER, BOSEILA et al., (1985) reported that the use of a single hormone injectable contraceptive leads to an Increase in the size of white pulps. LANDSHMAN and BLEIBERG (1979) observed that the effect of sex hormones on erythrepolesis in general and on lymphatic tissue in particular seem to vary in different animals.

The present results are also similar to those obtained by ANAGNOSTOU et al., (1976) and FUJII et al. (1985) who observed marked decrease in the white pulp and lymphocyte proliferation as well as occurence of lymphopenia after the use of double female sex hormones.

As regards the role of progesterone in production of splenic changes, SASAKI and ITO, (1981) reported that progesterone exerted almost no influence upon splenic pulps.

BESHIR et al. (1984) reported that administration of contraceptive pills in female guinea pig leads to significant stimulation of zona fasiculata of adrenal gland with subsequent increase in the plasma cortison level, corticosteroids are known to affect immune mechanism and lymphocyte depletion in lymphatic organs due to inhibitory effect of cortisone on cell division (FEIN et al., 1974). This may interpret the depletion of lymphocytes in both red and white pulp in rats treated for 15 and 21 days.

\section{REFERENCES}

Adieb, N.; El-Sharouni, S.; Abdel Zaher K. and Labib, $H$. (1986): Histological study of the liver, pancreas, kidney and suprarenal of the albino rat under the effect of Medroxy-progesterone acetate. Egypt. J. Hist. 9 (2): 249-355.

Anagnostou, A.; Zander, A. ; Barone, H. and Fried, W. (1976): Mechanism of increased splenic erythropoiesis in mice treated with estradiol benzoate. J.Lab. Clinc. Med. 88(5): 700-706.

Beck, P. (1969): Progestin enhancement of the plasma insuline response to glucose in rhesus monkeys. Diabetes 18: 146.

Beers, P.C. and Rosner, W. (1977): The dinding of estrogen in the liver of the rat: demonstration and endocrine influences. J. Steroid Biochem. 8: 251-258.

Beshir, S.R.; Abdar, M.S.M.; Sayed, O.F. El-Samney A. (1984): Effects of control ceptive pills on the suprarenal cortex and thyroid gland of Guinea Pig. Egypt. J. Histol. 7 (1): 77-84.

Assiut Vet. Med. J. Vol. 31 No. 62, July 1994. 
Beshir, S.R.; Anwar, M.E. and EI-Sayed, E.H. (1987): Histological changes produced by repeated injections of the androgenic hormone in male albino rats. Histological and histochemical changes in liver of male albino rats. Egypt. J. Histol. 10 (1): 3-8.

Birchmeier, P.J. (1969): Quantitative changes in mouse liver ultrastructure following cortisone and insulin administration. American J. of Biological Sciences 22, 965-978.

Boseila, A.W.; Ragab, A.M.F.; Saheh, N.A.; Hassan; M.I. and Bayomi, A. (1985): Histochemical localization of succinic dehydrogenase enzyme activity in the endometrium of female albino rat under the effect of different contraceptives. Egypt. J. Histol. 8: 215-221.

Chamness, G.C.; Costlow, M.E.; Mcguire, W.L. (1975): Estrogen receptor in rat liver and its dependence on prolactin. Steroids. 26.

Drury, R.A.B. and Wallington, E.A. (1980): Carleton's histological technique. 4th. Ed. Oxford Univ. Press New York \& Toronto.

Edris, R.; Grutierrez, J.; Makeoi M. and Groldzie, J. (1972): Injectable contraceptives in family planning. Proceedings, annual meeting of the AAP, Detroit. P. 103-113.

E1-Naggar, M.; Sammour, A.M.B and El-Assaly, M.M. (1986): Morphological and histochemical studies on the liver of chick embryo under the effect of female sex hormones. Egypt. J. Histol. (2): 36137.

Fein A.; Ornoy, A. and Nebel L. (1974): Effects of cortisone on fetal and neonatal thymo-lymphatic organd in rats. J. Anat. 117 (2): 223-237.

Fujii, T.L.; Hayama, T. and Kotani, M. (1985): Stimulating effect of natural estrogens on proliferation of hepatocytes in adult mice. Acta Anat. 121: 174-178.

Gaunt, R.; Kemington, J.W. and Saubos, S. (1939): Effects of progesterone and other hormones on liver glycogen. Proc.

Soc. Exper. Biol. and Med. 41:429.

Gershberg; H.; Zorrilla, E.; Hernaddez, A. and Hulse, M. (1969): Effect of medroxy progesterone acetate on serum insulin and growth hormone level in diabetic and potential diabetics. Obst. \& Gyn. 33: 383-389.

Gholi, W.M.; Sadek, M. Lucy, M.I. and Mikhail, Y. (1984): Effect of progesterone on the thymus gland of albino rats. Egypt. J. of Histol. 7 (1): 49-54.

Ghosh, M.N. (1971): Fundamentals of experimental pharmacology. pp. 85. Academic press, New York. 
Goodman, G.A.; Rall, W.T. and Taylor, P. (1991): Goodman and Gilmans. The pharmacological basis of therapeutics. 8th. ed. Pergamon press, New York, Oxford, Toronto.

Ingle, D.J. (1959): Effect of estrogen on liver glycogen in adrenalectomised rats. Droc. Soc. Exper. Biol. and Med. 100: 439 .

Landshman, N. and Bleiberg, I. (1979): Effect of estradiol on erythropoiesis and megakaryocytopoiesis in mice. Israal J. Med. Sci. 15: 140-146.

Nasonov, D.N. (1959): Reaction of protoplasm and spreading stimulation. Moscow. Leningrad. 1st ed.

Sang, C.S. and Kappas, A. (1969): The influence of hormones on hepatic functions. Prog. Liver Dis. 3:89.

Sasaki, K. and Ito, T. (1981): Effects of estrogen and progesterone on the spleen of the Mouse; A light and electron microscopic study. Arch. Histol. Jap. Vol. 441. No. 3, p. 203-213.

Wallaas, 0. (1952): Effects of estrogen on glycogen content of rat uterus. Acta. Endocrinol. 10:75.

\section{ILLUSTRATIONS OF FIGURES}

Plate I:

Fig. 1: A section in the control liver stained with H\&E, showing the structure of the liver lobule X 160 .

Fig. 2a\& b: A section in the liver treated with a mixture of estrogen \& progesterone for 7 days and stained with $H \& E$, showing dilation in the central vein (arrow) and portal area X 160.

Fig. 3a\& b: A section in the liver of rat treated with estrogen \& progesterone for 15 days and stained with $H$ \& E, showing lymphocytic infilteration and dilation in the blood sinusoids (arrow) $\times 200$.

Fig. 4a\& b: A section in the liver of rat treated with estrogen \& progesterone for 21 days and stained with $H$ \& $E$. , showing lymphocytic infilteration and vacuolation inside the cytoplasm of hepatocyte X 200.

\section{Plate II:}

Fig. 1: A section in the control liver of the rat stained with PAS for polysaccharides. X 320

Fig. 2: A section in the liver treated with (estrogen \& progesterone) for 7 days and stained with PAS for polysaccharides, showing increase positive reaction $X$ 125 
Fig. 3: A section in the liver treated with (estrogen \& progesterone) for 15 days of stained with PAS, showing, polysaccharides depletion. X 125

Fig. 4: A section in the liver treated with (estrogen \& progesterone) for 21 days, stained with PAS, showing depletion of polysaccharides X 320 ,

\section{Plate III:}

Fig. 1: A section in the control spleen of the rat stained with H \& E. X 200

Fig. 2: A section in the spleen treated with (estrogen \& progesterone) for 7 days stained with H \& E.X 200

Fig. 3: A section in the spleen treated with (estrogen \& progesterone) for 21 days, stained with H \& E. X 200.

Plate IV:

Fig. 1: A section in the control spleen stained for PAS reaction showing; the + ve reaction in the capsule \&. trabeculae $\times 125$.

Fig. 2: A section in the spleen treated with (estrogen \& progesterone) $E \& P$ for 7 days stained for PAS reaction $\times 125$

Fig. 3: A section in the spleen treated with (estrogen \& progesterone) E \& $P$ for 21 days stained for PAS reaction $\times 125$

Plate V:

Fig. 1: A section in the spleen of the control rat stained with Feulgen reaction for DNA X 200

Fig. 2: A section in the spleen treated with (estrogen \& progesterone) $E$ \& $P$ for 7 days, stained with Feulgen reaction for DNA $X 200$

Fig. 3: A section in the spleen treated with (estrogen \& progesterone) E \& $P$ for 21 days, stained with Feulgen reaction for DNA $\times 200$.

Assiut Vet. Med. J. Vol. 31 No. 62, July 1994. 
M.A. ATTIA et al.

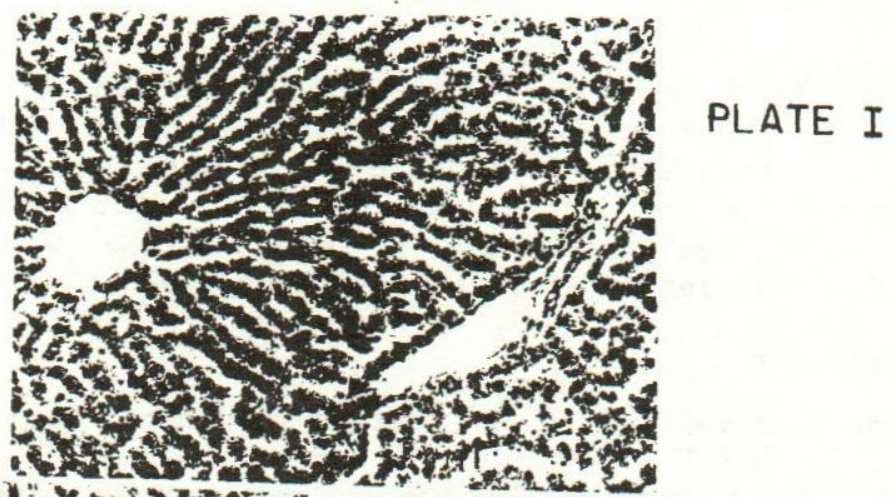

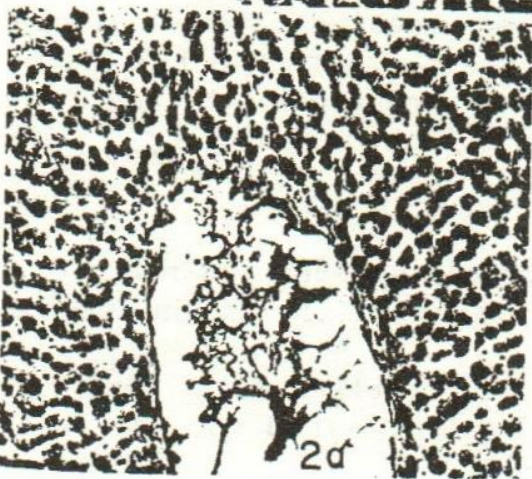
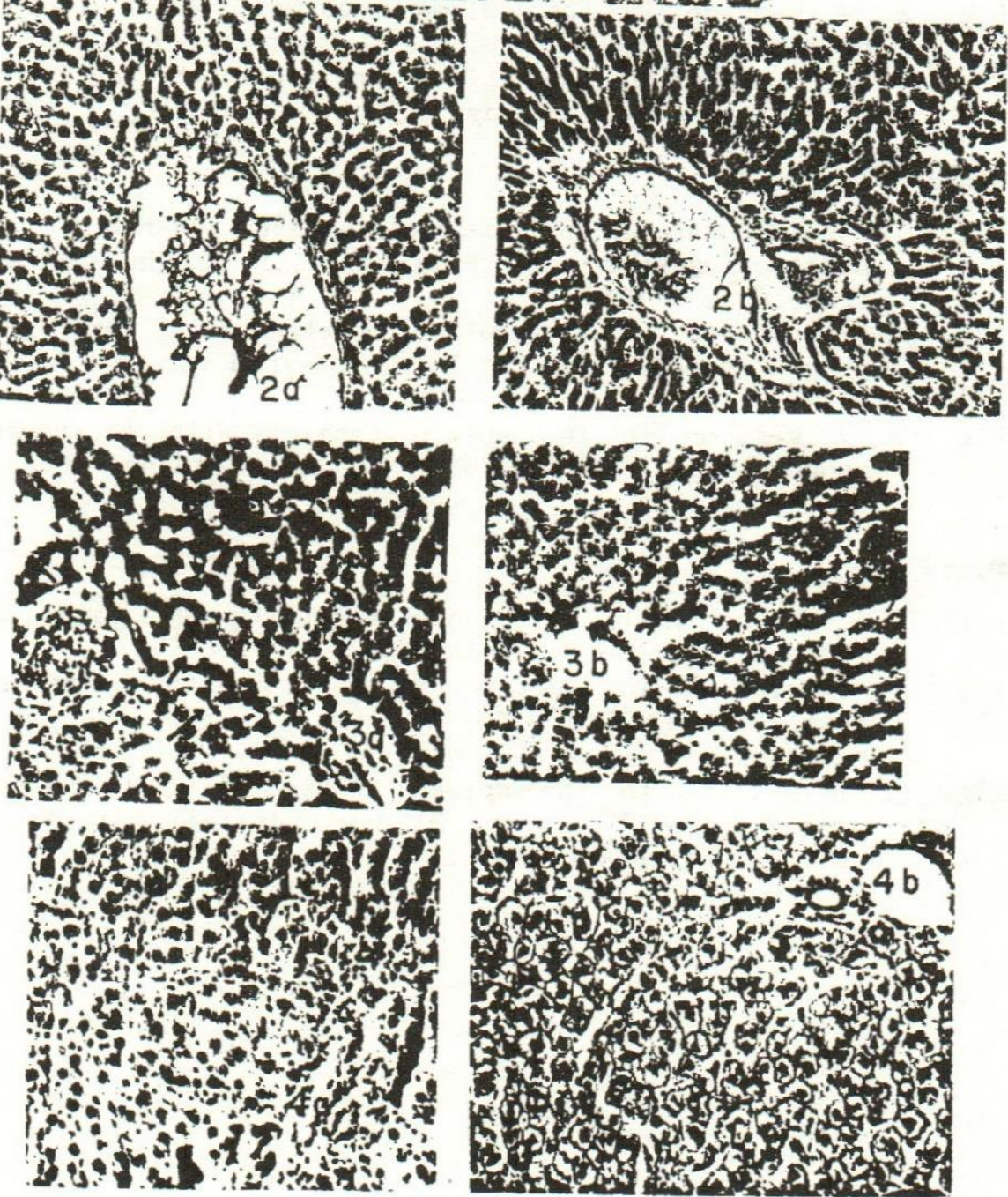

Assiut Vet. Med. J. Vol. 31 No. 62, July 1994. 

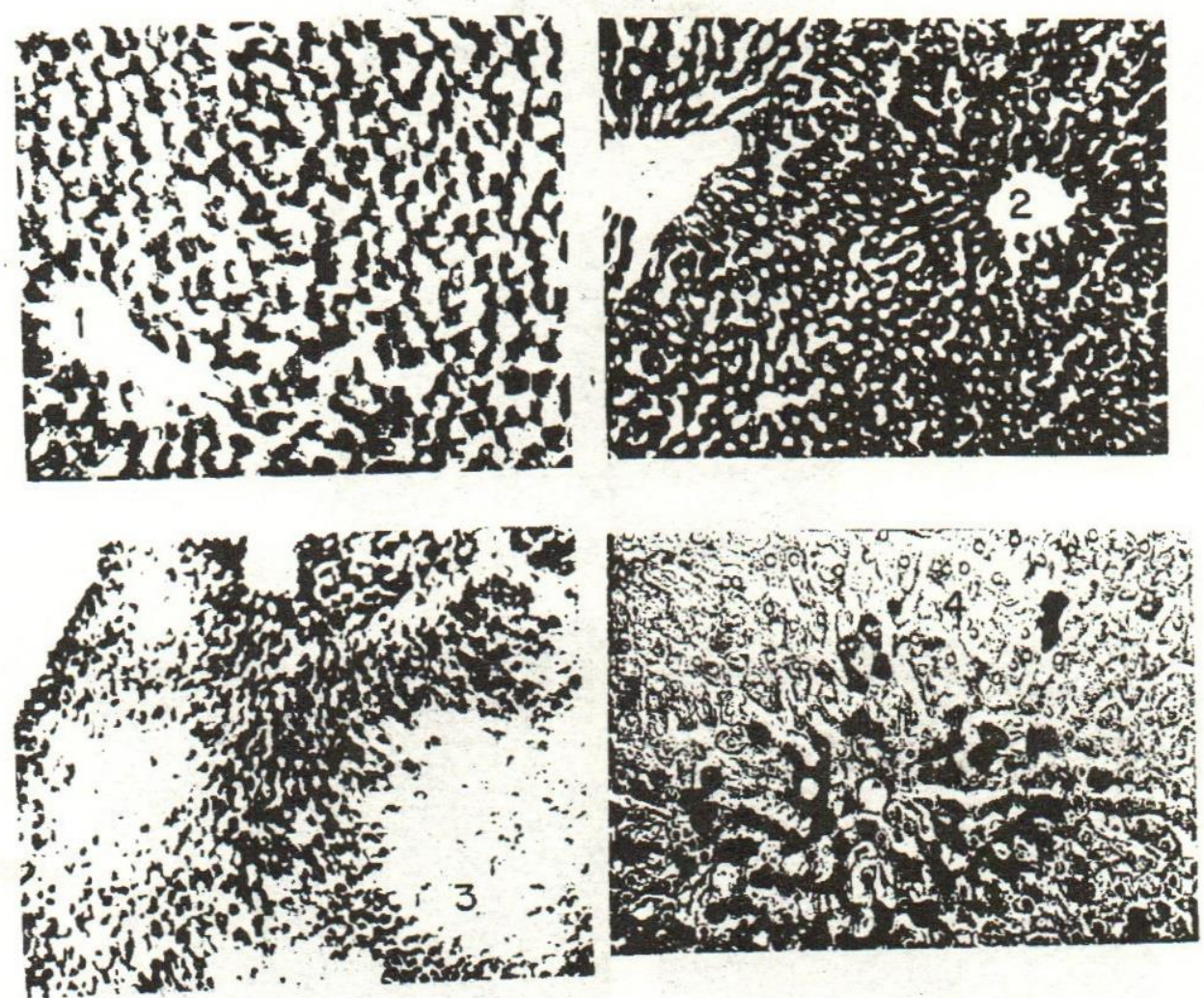

PLATE II

Assiut Vet. Med. J. Vol. 31 No. 62, July 1994. 


\section{M.A. ATTIA et al.}
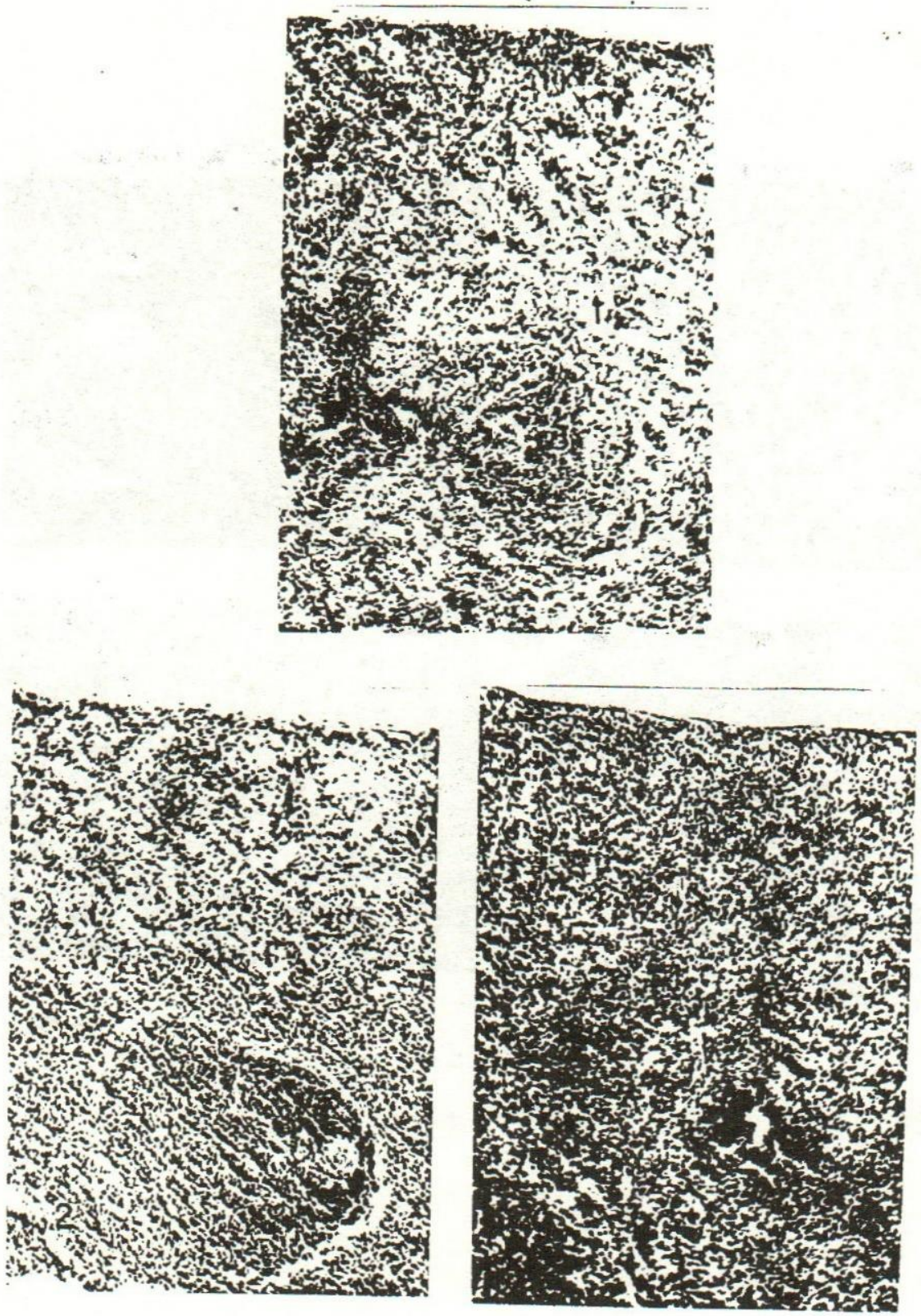

PLATE III

Assiut Vet. Med. J. Vol. 31 No. 62, July 1994. 

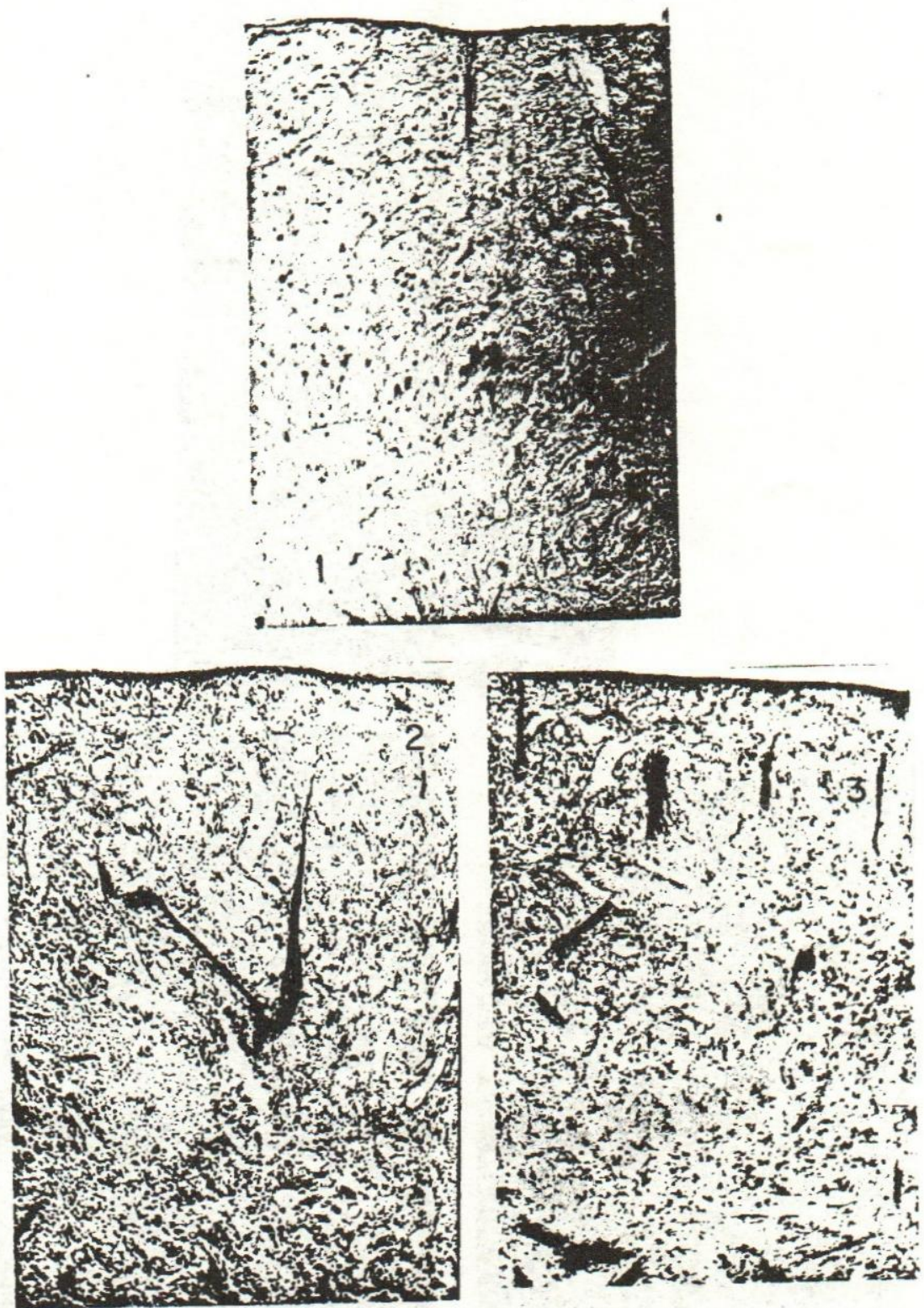

PLATE IV

Assiut Vet. Med. J. Vol. 31 No. 62, July 1994. 

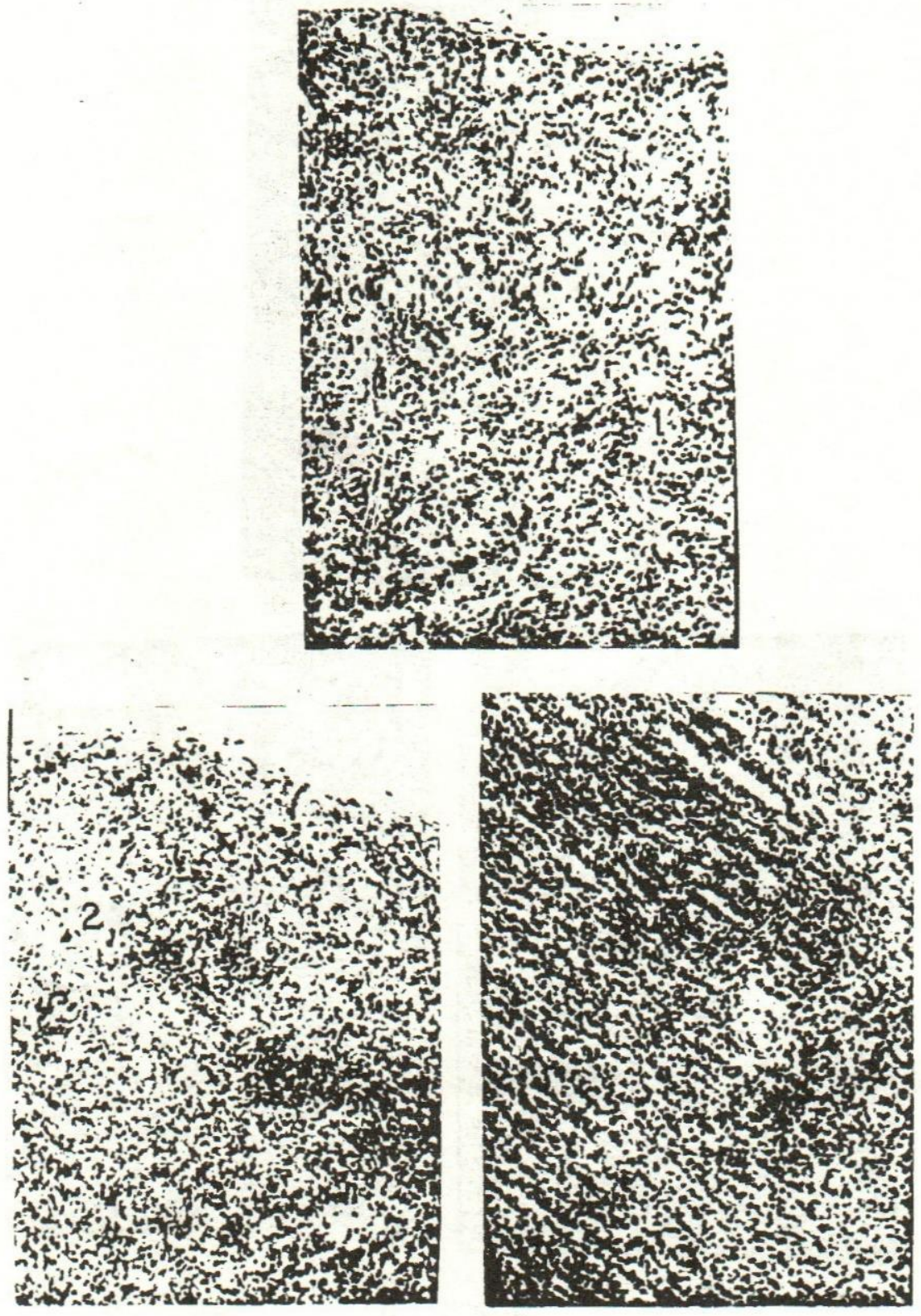

PLATE I 